ISSN: $2455-104 X$

DOI: $10.26761 /$ IJRLS.7.1.2021.1371

Volume 7, Issue 1 (January-June) 2021, 77-84, Paper ID: IJRLS-1371

Received: 14 January. 2021 ; Accepted: 26 January. 2021 ; Published: 30 January. 2021

Copyright $\Subset 2021$ Author(s) retain the copyright of this article. This article is published under the terms of the Creative Commons Attribution License 4.0

\title{
Awareness, Access and Utilization of \\ Electronic Journals among the Research \\ Scholars and Students of Madurai Kamaraj \\ University, Madurai: A Study
}

\author{
Dr. M. Balakrishnan'; C. Pandeeswaran² \\ Technical Assistant, Dr. T.P.M. Library, Madurai Kamaraj University, Madurai-21루 \\ Ph.D Research Scholar, Department of Library and Information Science, Madurai \\ Kamaraj University, Madurai-212 \\ mbala2717@gmail.com, ranjanpandian@gmail.com
}

\begin{abstract}
This paper focuses on the awareness, access and utilization of electronic journals among the Research Scholars and Students of Madurai Kamaraj University, Madurai. A questionnaire was used to collect data from the respondents. The sample is taken using simple random strategy. Out of 120 questionnaires distributed, 107 were received back. The study was conducted with an aim of to study the use of UGC-Infonet journals, to know the location of accessing E-journals, to study the purpose of utilization of e-journals, to study the time spends on access E-journals, to find out the search articles in electronic journals and to know the opinion about the problems faced while using e-journals. The major finding of the study, 39.3\% of the respondents spend less than one hour for accessing e-journals, $49.5 \%$ of respondents are the main purpose of using e-journals for writing articles/books, 53.3\% of the respondents search the articles in e-journals by using keywords, $73.8 \%$ of the respondents need the printed journals apart from using electronic journals and $37.4 \%$ of the respondents' opinion about the level of satisfaction of the Ejournals is good.
\end{abstract}

KEYWORDS: Awareness, Utilisation, Electronic journals, Library resources, User survey.

\section{INTRODUCTION}

Electronic journals are the simple electronic representation of a journal. In most cases, they replicate exactly the printed version of the journal, occasionally including additional information (such) as interactive graphs or external links), but in some cases there is no parallel print sources as the journal was 'born digital'. Any journal available on Internet can be called and electronic journal'. It may or may not have a print equivalent. There is no standard definition available for electronic journal. As a result, they have been called by various names, such as e-journals, 
virtual journals, paperless journals, online journals, scholarly electronic journals, networked journals and CD-ROM journal is one, which is available electronically to be used with the help of computer and other communication technologies.

Journals available on Internet are also referred to as Internet journals or networked journals. They include newspapers, magazines, periodicals and discussion lists. Perhaps, no other form of electronic publishing has received more attention than the electronic journals, particularly when libraries are experiencing cutbacks in funding. As they apply to scholarly research, there is a strong move among scholars to find less costly ways to support their research work.

\section{REVIEW OF LITERATURE}

Anjaiah Maothukuri (2014) conducted study on access and effective use of UGC-INFONET e-journals by the faculty members and research scholars at university library, Annamalai University. He examined that the two third of the faculty members and research scholars were using UGC-INFONET e- journals for teaching and research. The majority of the respondents accessing UGC-INFONET e- journals from university library and a large number of the respondents 41.6 present are fully satisfied with that consortium and given the rank to American Institute of physics second rank to American Institute of Society basis on the usage.

Baladhandayutham (2016) analysed ascertains the awareness and utilization of electronic journals by the members of faculty and research scholars of Madurai Kamaraj University, Madurai. It is found that $85.5 \%$ respondents access Open source journals, $78.6 \%$ respondents access E-Journals daily while $91 \%$ of the respondents use-journals for writing journal articles. $83.4 \%$ respondents access E-Journals in Library and $57.2 \%$ respondents cite that difficulty of accessing electronic journals is trouble in finding relevant information from E-journals. 67.6\% of the respondents 'opinion about usefulness of E-Journals is great extent. It is inferred from the Chi-square analysis that there is no association between the respondents' gender and their opinion about the level of satisfaction of the E -journals.

Pandeeswaran and Chellappandi (2018) undertook a study analyses Utilization of Wi-Fi Services in Hostel Students at Madurai Kamaraj University, Madurai. The study found that $66.4 \%$ of the respondents are using Wi-Fi of hostel students in the Madurai Kamaraj University, Madurai. 81.8\% of the respondents visit the internet every day. $35.5 \%$ of the respondents spend 1-2 hours in the internet per day for accessing sources. $60 \%$ of the respondents use of communication facilities for e-mail, $27.27 \%$ of the respondents uses the internet for writing journal articles. $62.7 \%$ of respondents are main problems faced while using internet is slow access speed and $73.6 \%$ of respondents are satisfied with e-resource rendered by Wi-Fi.

Prasantha Kumari and Lakshmi (2014) examined the use of UGC - Infonet consortium by the research scholars of Sri Venkateswara University. The study aimed at frequency of library visits, purpose of using e- journals, awareness about UGC- INFONET and place of Accessing and level of respondents were accessing e- journals through suggested that the authorities of Venkateswara University library needed to take necessary steps regarding the training programme for effective use of UGC- Infonet consortium.

Ranganathan (2013) Scholarly journals provide basic theoretical background as well as an input for the research at the higher education level. Because of the ICT and consortia approach for resource sharing, today majority of the research articles are available online. These online electronic journals are bargained, negotiated and acquired from the publishers and other database vendors and access for the same is enabled by the UGC-INFONET consortia on 7 


\section{Awareness, Access and Utilization of Electronic Journals among the Research Scholars and Students of Madurai Kamaraj University, Madurai: A Study}

X 24 hour basis at the desk top of the academician. This article focuses on the utilization of UGC-INFONET ejournal access by research scholar of Bharathidasan University. The main aim is to identify the needs and requirements of users in general and to know the use of UGC-INFONET e-journal access in the Bharathidasan University by research scholars. A survey was conducted through a questionnaire circulated among 90 research scholars study in the Bharathidasan University during 2012-2013.

Sudhakara and Kumar (2017) include information pertaining to the research methodology, population, sample, data collection and analysis. A comprehensive review of literature covering the period 2006 - 2017. Questionnaire survey method will be employed to study of Utilization of Journals: A Survey of University Libraries in South Karnataka. Questionnaire will be framed to collect the feedback from users to meet the objectives of this study. Data collected will be subjected for statistical analysis to prove objectives and hypothesis. This article reviews the literature on the utilization of journals. The literature includes journal articles, books, reports and monographs etc., published inside and outside India.

Sudhier (2011) the studies about the e-resources and consortia initiatives of scholarly journals have been important for both librarians and publishers. This article intends to provide an overview of the e-journals as a means of scholarly communication with emphasis on consortia initiatives in India. Concept of e-journals, kinds of e-journals, Indian open access journals and consortia are discussed in detail. Indian consortia initiatives include: INDEST, FORSA, UGC-INFONET, N-LIST, CSIR e- journal consortia, DRDO, ICMR, HELINET, Space Net of ISRO, CeRA of ICAR, MCIT Library Consortium and IIM Consortium. Hence the paper provides an insight on what are the consortia initiatives functioning in India. This will be useful for the information professionals and researchers in the area of LIS.

Velmurugan (2013) in a case study aims to explore the usage of library information resources among the students of Siva Institute of Frontier Technology at Chennai. A total of number 175 (distributed 25 questionnaire in each department) well-structured questionnaire was distributed to the students of undergraduates out of which 126 were returned dully filled in by the user's community and the overall response rate was 72.00 percent. Percentage analysis was used to analyze the data which are obtained and descriptive analysis was used to interpret the results. The results revealed that various issues such as analysis of user's needs, speed of Internet connection, provision of easy access to e-journals, use of search engines and orientation and training programmes for students and staff members

\section{OBJECTIVES}

* To study the use of electronic journals

* To know the location of accessing electronic journals.

* To study the purpose of utilization of e-journals.

* To study the time spends on access E-journals.

* To find out the search articles in electronic journals

* To know the opinion about the problems faced while using e-journals

* To study the level of satisfaction of the respondents regarding the use of E-journals.

\section{RESEARCH METHODOLOGY}

The present study is a survey method using a questionnaire. The questionnaire contained relevant questions pertaining to awareness with respect to e-journals. For this purpose a total of 120 questionnaires were distributed 
among the research scholars and students. Out of the 120 questionnaires distributed, 107 valid questionnaires were collected and then data was analyzed, tabulated, interpreted and graphically represented in this paper.

\section{STATEMENT OF THE PROBLEM}

The present research entitled, "Awareness, Access and Utilization of Electronic Journals among the Research Scholars and Students of Madurai Kamaraj University, Madurai: A Study'.

\section{SCOPE OF THE STUDY}

The topic of the research study is "Awareness, Access and Utilization of Electronic Journals among the Research Scholars and Students of Madurai Kamaraj University, Madurai: A Study”. The target group of this study includes library users of Madurai Kamaraj University. The target respondents in other its colleges or universities are not included in this study. There is a scope for other future researchers to take this area of the study.

\section{BIBLIOGRAPHY RENDERING STYLE}

The report format follows the American Psychological Association (APA) manual of style in rendering the bibliography with slight modifications regarding Indic and Islamic names.

\section{DATA ANALYSIS AND INTERPRETATION}

Table 1: Distribution of respondents by gender

\begin{tabular}{|c|c|c|c|}
\hline \multicolumn{2}{|c|}{ Particulars } & No. of Respondents & Percentage \\
\hline \multirow{2}{*}{ Gender } & Male & 58 & 54.2 \\
\hline & Female & 49 & 45.8 \\
\hline \multicolumn{2}{|r|}{ Total } & 107 & 100 \\
\hline \multirow{5}{*}{ Age } & Below 25 & 9 & 8.4 \\
\hline & $26-30$ & 39 & 36.4 \\
\hline & $31-35$ & 31 & 29.1 \\
\hline & $36-40$ & 18 & 16.8 \\
\hline & 41 and above & 10 & 9.3 \\
\hline \multicolumn{2}{|r|}{ Total } & 107 & 100 \\
\hline
\end{tabular}

\section{Source: Primary data}

Table 1 shows the distribution of respondents by Gender. In this study, 58(54.2\%) respondents are male whereas $49(45.8 \%)$ respondents are female. Hence more than half of the respondents belong to the category of male. The above Table also indicates that among the overall 107 respondents, a majority of 39 (36.4\%) respondents belong to the age group between 26 and 30, and it is followed by 31 (29.1\%) respondents between 31 and 35 age group, 18 (16.8\%) respondents between 36 and 40 age group, $10(9.3 \%)$ respondents between 41 and above age group and 9 (8.4) of them below 25 age group.

Table 2: Location to access the electronic journals

\begin{tabular}{|c||c||c||c|c||c||}
\hline \multirow{2}{*}{ S. No } & Options & $\begin{array}{c}\text { No. of overall } \\
\text { responses }\end{array}$ & $\begin{array}{c}\text { \% of valid } \\
\text { respondents } \\
\mathbf{N = 1 0 7}\end{array}$ & $\begin{array}{c}\text { \% of overall } \\
\text { responses } \\
\mathbf{N = 1 6 4}\end{array}$ & Rank \\
\hline \hline 1 & $\begin{array}{l}\text { Department computer } \\
\text { labs }\end{array}$ & 38 & 35.5 & 23.2 & 3 \\
\hline \hline 2 & University library & 47 & 43.9 & 28.7 & 1 \\
\hline
\end{tabular}


Awareness, Access and Utilization of Electronic Journals among the Research Scholars and
Students of Madurai Kamaraj University, Madurai: A Study

\begin{tabular}{|c|c|c|c|c|c|}
\hline$\overline{5}$ & "Hostel & 42 & 39.3 & 25.6 & $\overline{22}$ \\
\hline $\bar{~} 6$ & Internet cafe & 8 & 7.5 & 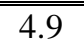 & $\overline{5}$ \\
\hline 77 & Others & 29 & 27.1 & 17.7 & 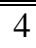 \\
\hline & Total & 164 & 153.3 & 100 & \\
\hline
\end{tabular}

Source: Primary data

Multiple Responses

It is observed from the table 2 that $35.5 \%$ respondents access the electronic journals in department computer labs and it has got the third rank, 43.9\% respondents university libraries and it has got the first rank, 39.3\% respondents hostels and it has got the second rank, $7.5 \%$ respondents internet cafes and it has got the fifth rank and $27.1 \%$ respondents access the some other places and it has got the fourth rank.

Table 3: Time spent for using e-journals per day by the respondents of status

\begin{tabular}{|c|c|c|c|c|c|c|}
\hline \multirow[b]{2}{*}{$\begin{array}{l}\text { S. } \\
\text { No }\end{array}$} & \multirow[b]{2}{*}{ 1. Status of users } & \multicolumn{4}{|c|}{ Hours (\%) } & \multirow{2}{*}{$\begin{array}{l}\text { 2. Total } \\
\mathrm{N}\end{array}$} \\
\hline & & $\begin{array}{l}\text { Less than } \\
\text { one hour }\end{array}$ & $1-2$ hours & $2-3$ hours & $\begin{array}{c}\text { More than } 3 \\
\text { hours }\end{array}$ & \\
\hline 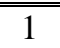 & PG Students & 10 & $99(28.1)$ & $\overline{5(15.6)}$ & $3(9.4)$ & 32 \\
\hline 2 & "M.Phil Scholars & 4 4(30.8) & $7(53.8)$ & $2(15.4)$ & - & 13 \\
\hline 3 & Ph.D Scholars & $23(37.1)$ & $19(30.6)$ & $111(17.7)$ & $9(14.5)$ & 62 \\
\hline & Total & 42 & 35 & 18 & 12 & 107 \\
\hline
\end{tabular}

\section{Source: Primary data}

Table 3 describes the time spent for using e-journals per day by the respondents status-wise. Among the respondents representing from Post graduate students, a majority of 15 (46.9\%) respondents spend less than one hour for using ejournals per day and it is followed by 9 (28.1\%) respondents spend 1-2 hours, 5 (15.6\%) spend 2-3 hours and 3 (9.4\%) spend more than three hours respectively. Of the respondents belonging to M.Phil scholars, a majority of 7 (53.8\%) respondents spend 1-2 hours for using e-journals per day and it is followed by 4 (30.8\%) spend less than one hour and $2(15.4 \%)$ spend 2-3 hours respectively. Of the respondents belonging to Ph.D scholars, a majority of $23(37.1 \%)$ respondents spend less than one hour for using e-journals per day and it is followed by $19(30.6 \%)$ spend 1-2 hours, $11(17.7 \%)$ spend 2-3 hours and 9 (14.5\%) spend more than 3 hours respectively. It is concluded that $39.3 \%$ of the respondents spend less than one hour for accessing electronic journals in university.

Table 4: Purpose of using electronic journals $(\mathrm{N}=107)$

\begin{tabular}{|c|c|c|c|c|c|}
\hline $\begin{array}{l}\text { S. } \\
\text { No }\end{array}$ & Purpose & $\begin{array}{c}\text { No. of } \\
\text { overall } \\
\text { responses }\end{array}$ & $\begin{array}{c}\% \text { of valid } \\
\text { respondents } \\
\mathrm{N}=107\end{array}$ & $\begin{array}{c}\text { of overall } \\
\text { responses } \\
\mathrm{N}=194\end{array}$ & Rank \\
\hline 1 & For research work & 33 & 30.8 & 17 & 4 \\
\hline 2 & For writing articles/ books & 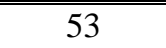 & 49.5 & 27.3 & 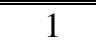 \\
\hline 3 & For keeping up-to-data information & 19 & 17.8 & 9.8 & 5 \\
\hline 4 & $\begin{array}{l}\text { For finding relevant information in the } \\
\text { area of specialization }\end{array}$ & 16 & 15 & 8.2 & 6 \\
\hline 5 & For UGC NET & 34 & 31.8 & 17.5 & 3 \\
\hline 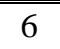 & For study purpose & 39 & 36.4 & 20.1 & 2 \\
\hline & Total & 194 & 181.3 & 100 & \\
\hline
\end{tabular}

Source: Primary data

Multiple Responses 
It could be noticed from the above Table 4 that $30.8 \%$ of the respondents use the e-journals for research work and it has got the fourth rank, $49.5 \%$ for writing articles/ books and it has got the first rank, $17.8 \%$ for keeping up-to-data information and it has got the fifth rank, $15 \%$ for finding relevant information in the area of specialization and it has got the sixth rank, $31.8 \%$ for UGC NET and it has got the third rank and $36.4 \%$ for study purpose and it has got the second rank. Therefore majority of the respondents are main purpose of using e-journals for writing articles/ books.

Table 5: Opinion about search the articles in electronic journals $(\mathrm{N}=107)$

\begin{tabular}{|c|c|c|c|c|c|}
\hline S. No & Options & $\begin{array}{c}\text { No. of overall } \\
\text { responses }\end{array}$ & $\begin{array}{c}\% \text { of valid } \\
\text { respondents } \\
\mathrm{N}=107\end{array}$ & $\begin{array}{c}\% \text { of overall } \\
\text { responses } \\
\mathrm{N}=179\end{array}$ & Rank \\
\hline 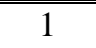 & Keyword & 57 & 53.3 & 31.8 & 1 \\
\hline 2 & Subject & 49 & 45.8 & 27.4 & 2 \\
\hline 3 & Author & 12 & 111.2 & 6.7 & $\overline{5}$ \\
\hline 4 & Journal title & 27 & 25.2 & 15.1 & 4 \\
\hline 5 & Title of article & 34 & 31.8 & 19 & 3 \\
\hline \multicolumn{2}{|r|}{ Total } & 179 & 167.3 & 100 & \\
\hline
\end{tabular}

Source: Primary data

Multiple Responses

Table 5 reveals the search the articles in e-journals. It is inferred from the above table, 53.3\% of the respondents search the articles in e-journals by using keyword and it has got the first rank, $45.8 \%$ of the respondents by subjectwise and it has got the second rank, $11.2 \%$ of the respondents by author-wise and it has got the fifth rank, $25.2 \%$ of the respondents by journal title-wise and it has got the fourth rank and $31.8 \%$ respondents by title of article-wise and it has got the third rank. Hence a majority of the respondents search the articles in e-journals by using keyword.

Table 6: Opinion about the problems faced while using e-journals $(\mathrm{N}=107)$

\begin{tabular}{|c|c|c|c|c|c|}
\hline $\begin{array}{l}\text { S. } \\
\text { No }\end{array}$ & Problems & $\begin{array}{c}\text { No. of overall } \\
\text { responses }\end{array}$ & $\begin{array}{c}\% \text { of valid } \\
\text { respondents } \\
\mathrm{N}=107\end{array}$ & $\begin{array}{c}\text { \% of overall } \\
\text { responses } \\
\mathrm{N}=173\end{array}$ & Rank \\
\hline 1. & Lack of knowledge to use & 52 & 48.6 & 30.1 & 1 \\
\hline 2. & "Slow Internet Bandwidth & 41 & 38.3 & 23.7 & 2 \\
\hline 3. & $\begin{array}{l}\text { Technical Problems } \\
\text { Down) }\end{array}$ & 27 & 25.2 & 15.6 & 4 \\
\hline 4. & Frequent Power cut & 8 & 7.5 & 4.6 & 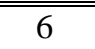 \\
\hline 5. & $\begin{array}{l}\text { Lack of assistance by library } \\
\text { staff }\end{array}$ & 13 & 12.1 & 7.5 & 5 \\
\hline 6. & Restricted access & 32 & 29.9 & 18.5 & 3 \\
\hline \multicolumn{2}{|r|}{ Total } & 173 & 161.7 & 100 & \\
\hline
\end{tabular}

Source: Primary data

Multiple Responses

It can be observed from Table 6 that a majority of $48.6 \%$ of the respondents state that lack of knowledge to use is main problem faced while using e-journals and it has got the first rank, 38.3\% of the respondents slow internet bandwidth and it has got the second rank, 25.2\% respondents technical problems (Server Down) and it has got the fourth rank, $7.5 \%$ of the respondents frequent power cut and it has got the sixth rank, $12.1 \%$ of the respondents lack of assistance by the library staff and it has got the fifth rank and $29.9 \%$ of the respondents restricted access and it has got the third rank. 
Awareness, Access and Utilization of Electronic Journals among the Research Scholars and Students of Madurai Kamaraj University, Madurai: A Study

Table 7: Need printed journal in addition to electronic journals

\begin{tabular}{|c||c||c|c|}
\hline S. No & 3. Opinion & No. of Respondents & 4. Percentage \\
\hline \hline 1. & Yes & 79 & 73.8 \\
\hline \hline 2. & No & 28 & 26.2 \\
\hline \multicolumn{2}{|c|}{ Total } & $\mathbf{1 0 7}$ & $\mathbf{1 0 0}$ \\
\hline
\end{tabular}

Source: Primary data

Table 7 reflects the need printed journal in addition to e-journals. Among the respondents 79 (73.8\%) need printed journals in addition to e-journals and 28 (26.2\%) do not need printed journal in addition to e-journals. The study proves that $73.8 \%$ of the respondents need the printed journals apart from using electronic journals.

Table 8: Level of satisfaction of the e-journals by respondents of residential sector

\begin{tabular}{||c|c|c|c|c||c||c||}
\hline \multirow{2}{*}{ S. No } & \multirow{2}{*}{$\begin{array}{c}\text { 5. Residential } \\
\text { sector }\end{array}$} & Very Good & Good & Satisfactory & $\begin{array}{c}\text { Not } \\
\text { satisfactory }\end{array}$ & $\begin{array}{c}\text { Tal } \\
\text { N }\end{array}$ \\
\cline { 2 - 6 } & Rural & $13(28.3)$ & $19(41.3)$ & $9(19.6)$ & $5(10.9)$ & 46 \\
\hline 2. & Urban & $15(24.6)$ & $21(34.4)$ & $19(31.1)$ & $6(9.8)$ & 61 \\
\hline & Total & $\mathbf{2 8}$ & $\mathbf{4 0}$ & $\mathbf{2 8}$ & $\mathbf{1 1}$ & $\mathbf{1 0 7}$ \\
\hline
\end{tabular}

Source: Primary data

Data presented in table 8 reveal the level of satisfaction of the e-journals by respondents of residential sector. The study attempts to get the opinion from the respondents from rural areas, a majority of 19(41.3\%) respondents' level of satisfaction of the e-journals is good and it is followed by 13(28.3\%) of them opine that very good, 9 (19.6\%) of them satisfactory and 5(10.9\%) of them not satisfactory respectively. Among the respondents from urban areas, a majority of 21(34.4\%) respondents' level of satisfaction of the e-journals is good and it is followed by 19(31.1\%) of them satisfactory, $15(24.6 \%)$ of them very good and 6(9.8\%) of them not satisfactory respectively. Therefore $37.4 \%$ of the rural and urban respondents' opinion about the level of satisfaction of the E-journals is good.

\section{MAJOR FINDINGS}

* $54.2 \%$ of the respondents belong to the male category

* Majority of 39 (36.4\%) respondents belong to the age group between 26 and 30

* $57 \%$ of the respondents belong to urban areas

* Majority of the respondents belong to category of Ph.D scholars

* $43.9 \%$ of respondents access the electronic journals by university libraries

* $39.3 \%$ of the respondents spend less than one hour for accessing e-journals

* $49.5 \%$ of the respondents are main purpose of using e-journals for writing articles/ books

* 53.3\% of the respondents search the articles in e-journals by using keywords

* $48.6 \%$ of the respondents state that lack of knowledge to use is main problem faced while using e-journals

* $73.8 \%$ of the respondents need the printed journals apart from using electronic journals

* $37.4 \%$ of the respondents' opinion about the level of satisfaction of the E-journals is good 


\section{CONCLUSION}

Electronic Journals or Online journals act as an effective tool to meet information needs of the user community, such as research scholars and students, whereas budget allocation, changing price models and license agreements have made library collection policy as a problematic issue. Regularly conduct of orientation/ training program for the UGC consortium, Installation of more computer terminals and increasing network accessibility, Regular power supply and Introduce written instruction for subject specific resources. E-journals have turned out as a vital knowledge base for our research community. Efficient management of time has been made possible through their usage. Thus the present scenario entails for spreading of awareness among the users and for development of proper infrastructure within the library system to achieve significant results.

\section{SUGGESTIONS}

* It is suggested that: Regular conduct of orientation/training programme for the UGC consortium

* It is suggested that: Installation of more computers terminals and increasing network accessibility

* It is suggested that: Regular power supply

* It is suggested that: Introduce written instruction for subject specific resources

\section{REFERENCES}

[1] Anjaiah Maothukuri (2014). Access and Effectiveness of UGC- Infonet E-journals by the faculty Members and Research Scholars at University Library, Annamalai University, Tamil Nadu: A Case study. International Journal of Digital Library services, 4(2), 30-43.

[2] Baladhandayutham, A. (2016). Awareness and Utilization of Electronic Journals by the Members of Faculty and Research Scholars of Madurai Kamaraj University, Madurai. International Journal of Multidisciplinary Research and Modern Education (IJMRME), II(II): 455-461

[3] Krishnan, Ramesh (2019). "Use and Impact of Electronic Journals among the Users of Periyar University in Salem, Tamilnadu, India". Library Philosophy and Practice (e-journal). 2199

[4] Pandeeswaran, C., \& Chellappandi, P. (2018). Utilization of Wi-Fi Services in Hostel Students at Madurai Kamaraj University, Madurai. International Journal of Information Retrieval and Management, 6(12), 26-28.

[5] Prasantha Kumari, M. \& Lakshmi, S. (2014). Use of Electronic journals through UGC- Infonet consortium by the research scholars of Sri Venkateswara University, Tirupati: A study. IOSR Journal of Humanities and social science, 19(9), 67-74.

[6] Ranganathan, C. (2013). "Utilization of UGC-INFONET e-journal access by Research Scholars of Bharathidasan University in Trichurappalli: A Case Study", International Journal of Engineering Research \& Technology (IJERT), 2(4): 2162-2174.

[7] Sudhakara \& Kumar, Hemantha. (2017). Utilization of Journals - A survey of University Libraries in South Karnataka: A Review. IP Indian Journal of Library Science and Information Technology, 2(2): 52-64.

[8] Sudhier, K.G. (2011). E- Journal Consortia and Indian Consortia Initiatives: An Overview. PEARL - A Journal of Library and Information Science, 5(2), 39-49.

[9] Velmurugan, C. (2013). Awareness and Usage of Electronic Journals among Undergraduate Students in an Engineering College Central Library, Chennai, Tamilnadu: A Case Study. Journal of Advances in Library and Information Science, 2(3): 124-129.

[10] http://www.lisbdnet.com/electronic-journal-e-journal/ 